B 205

A4 S5

916

opy 1

\title{
The Growing of Gold
}
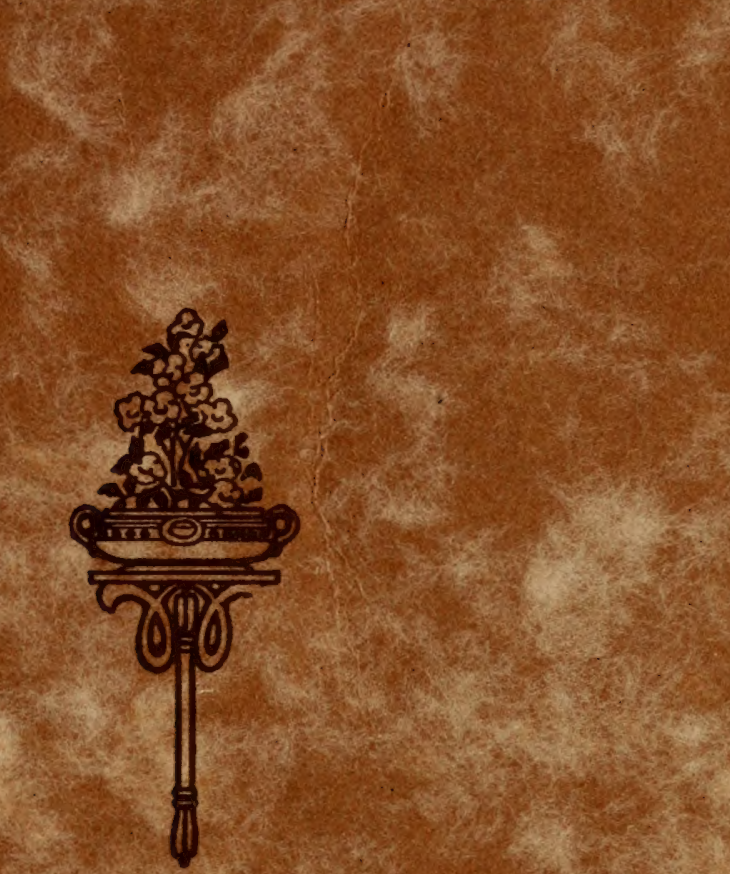

Published by

A. A. BERRY SEED CO. CLARINDA, IOWA 




Facts About Growing Alfalfa, the Practical Gold Mine for the Farmer of Today

\author{
By J. F. SINN \\ of the"
}

A. A. BERRY SEED CO.

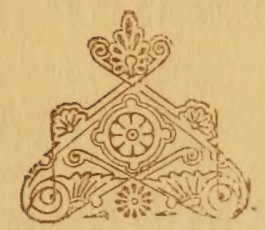

Copyrighted 1916

A. A. BERRY SEED CO.

\title{
Price 25 Cents
}

\section{Printed and Published by A. A. BERRY SEED COMPANY CLARINDA, IOWA}




\section{SB205 . A4S5 1916}

\section{CONTENTS}

Chapter

Page

INTRODUCTION ........... 5

1 ALFALFA IN AMERICA......... 7

2 SELECTION OF LAND. . . . . . . . . 12

3 INOCULATION AND FERTILIZA-

TION .................. 15

4 SEEDING OF ALFALFA.......... 20

5 CARING FOR ALFALFA......... 24

6 HARVESTING OF ALFALFA...... 28

7 SCIENTIFIC FEED VALUE....... 32

8 ALFALFA THE MONEY CROP..... 37

9 THE BEST ALFALFA SEED...... . 43

10. WHAT OTHERS SAY .......... 46

$\therefore \therefore$ ALFALFA FACTS WORTH REMEM-

BERING ............... 51

WEIGHTS AND MEASURES..... 53

(C) A $A 228414$

APR -61916 


\section{THE GROWING OF GOLD}

\section{INTRODUCTION.}

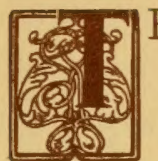

HE purpose of writing this little booklet is to set forth the facts on growing Alfalfa; to give our friends a condensed and abbreviated reference book that will be useful and helpful to every one who is interested in the upbuilding of the farm, and getting greater profits from it.

In writing this book, the writer has frequently referred to Bulletin No. 137 of Iowa Agricultural Station, and the best works that he could find on Alfalfa. It has been the aim to give the most authentic information on this subject that could be found and we are sure our customers and friends will find it of great assistance to them in getting the most out of the crop.

There is an unlimited amount of wealth in the growing of Alfalfa, so the writer has entitled this booklet "The Growing of Gold." This name is most fitting, as it is easy to grow gold by using plenty of Alfalfa Seed. You should get our "Yellow as Gold Seed," and sow it freely on your farm on a well prepared seed bed, and then you will better appreciate this book, and more fully understand "The Growing of Gold." 


\section{THE GROWING OF GOLD}

It is the earnest desire of the writer to impress upon every reader of this book the great importance of growing Alfalfa and I hope that every farmer that has a farm will start at once "The Growing of Gold," or in other words "The Growing of Alfalfa." It is bound to bring joy and wealth to him the same as it has to the many thousands of other farmers who are no more favored than you.

There may be instances that you know of where Alfalfa has been a failure, but this does not condemn the plant in the least, and you should strive all the harder to grow Alfalfa successfully. It can be grown on your farm and the writer will feel that his efforts have accomplished the purpose intended if this book is the means of influencing you to test it out yourself and experience the great reward offered to all who make a success of growing Alfalfa.

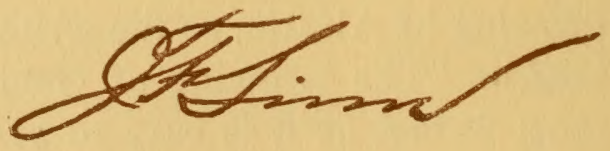




\section{THE GROWING OF GOLD}

CHAPTER I.

\section{ALFALFA IN AMERICA.}

Fof LFALFA is a new plant for America, generally speaking, but the plant itself is no wise new, as it has been grown for more than 2,000 years. Alfalfa was first grown in Asia and from there it spread westward throughout the entire of Europe, where it has been growing with the greatest of success for many centuries. It was brought to South America by the Spaniards and it gradually worked northward, having been grown for more than 200 years in Mexico before introduced into the United States. We are indebted to them for introducing it in the United States, as it was first grown in California and then spread to other Western States and has gradually worked eastward until it has penetrated every State to the Atlantic.

Alfalfa was first grown in California in the early 50's and was not grown in the great Alfalfa States of Kansas and Nebraska until late in the 70's. You can now hardly find a progressive farmer in these States who is not growing more or less Alfalfa. West of the Missouri River 
Alfalfa is recognized as the best paying crop that can be grown and has turned much of the dry, barren waste into a world of wealth. What it has done for the Western farmer it will do for the Eastern farmer. It is fast becoming the best paying crop that can be grown in the East, especially by the dairy farmer. Alfalfa will add untold wealth to the corn-belt farmer, who has been constantly cropping the land with corn, taking away the nitrogen and humus which alfalfa replaces.

It is hard to estimate the worth of Alfalfa, but it is surely King of the forage plants and every farmer should be growing it. Henry Wallace says that every farmer in Iowa who has a quarter section should at least have 10 acres of Alfalfa. It is high time that each and every farmer should recognize the value of this wonderful crop.

Alfalfa has made great advancement in the United States in the past fifty years, but it has only been in the past few years that its full value has been realized. Therefore Alfalfa growing is in its infancy. From now on Alfalfa growing should make very rapid progress, and the farmer who is slow about starting to grow this plant is losing out on the best money making crop that he could plant. 


\section{THE GROWING OF GOLD}

It is strange that a plant that has such sterling worth as Alfalfa is not grown more generally by all farmers. Some writers have led the farmer to believe that Alfalfa is hard to grow, and many think they could not make a success of it. This is where Alfalfa unjustly got a great setback, for it is not difficult to grow. In fact it can be grown on nearly every farm in nearly every State in the Union. In Iowa the Experimental Station shows that Alfalfa is a much surer crop than clover. Prof. Hughes of the Iowa State College reports that out of over 1,000 reports from farmers in Iowa on growing Alfalfa, there was less than 13 per cent failures, while on growing clover the per cent was much greater.

Alfalfa is a crop of wide adaptability and the growing of it need not be confined to any the Experimental Station shows that Alfalfa is being grown successfully all over Asia and Europe and in a latitude as far north as 68 degrees north latitude recommends it as a very hardy plant. Alfalfa is now being grown successfully in every State in the Union and you will now find small fields here and there throughout the Eastern States as well as the Northern and Southern. Alfalfa is no longer a plant of the Western States. We have customers all over the United States reporting the great success they 


\section{THE GROWING OF GOLD}

have had with our seed. So the writer does not hesitate about urging each and every farmer to start growing it. It does not take long to test it out, and if you will properly prepare the ground and use good hardy seed there is no cause for failure.

When you stop to consider the worth of an acre of Alfalfa, you then can begin to realize the importance of studying this plant and the reason you should grow it. An acre of Alfalfa is capable of producing all the way from $\$ 25.00$ to $\$ 100.00$, depending upon the season and conditions. In the corn belt it is capable of doubling the income of corn. Its value is appreciated in the corn belt, for Alfalfa and corn make an ideal balanced ration, and the stock raisers cannot well afford to be without it.

The high feed value of Alfalfa will be taken up in another chapter, one which will be of great interest to you. Don't overlook the value of Alfalfa as a feed, as there is no other forage plant equal to it. It far excels clover and all other legumes, and not only that, but it is a nitrogen gathering plant and is excellent for rebuilding the soil. It is truly said that every acre seeded to Alfalfa increases the value of the land $\$ 100.00$. 


\section{THE GROWING OF GOLD}

Whenever you find a farm that has several Alfalfa fields growing, you will usually find a nice set of farm buildings, and a farm that is not for sale. The owner realizes he has as good a paying proposition as he could wish for and is not anxious to part with a sure thing. You will find that real estate values soon increase when Alfalfa is grown. Alfalfa has brought more wealth to the Western States than their gold mines, and all other mines included. It is called by some writers the "Wonder Crop" and it is well entitled to this name, as it is wonderful what wealth it will bring. It is to be hoped that every farmer who has a farm will start growing Alfalfa at once.

You can grow Alfalfa on your farm and there is no reason why you should hesitate about starting. If you do not start now, it will be safe to say you will be growing it ten years from now. Why let ten years of the best part of your life pass by before starting on this road to wealth? 


\section{$T H E$ GROWING OF GOLD}

CHAPTER II.

\section{SELECTION OF LAND.}

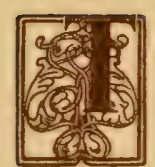

HE successful growing of Alfalfa depends quite largely on getting land adapted to the plant. This does not mean that it is hard to find land suitable for Alfalfa, as on nearly every farm certain portions or fields will grow Alfalfa, some parts being much better adapted to the plant than others. So it is well to be careful in selecting your field and get the piece that will bring you the best returns. On some farms every acre might be well suited to growing Alfalfa, but this is not always the case.

When selecting your ground for Alfalfa growing, see that you decide on a field that is well drained, and that it has a porous sub-soil, and also try to select fertile soil. Well drained soil does not mean some high hill, but on the other hand, much better results would be obtained from a good piece of bottom land that is not wet and water does not stand near the surface; or a good field of rolling land that is sufficiently fertile. For best results it might be well to first grow Cow Peas or some legume, preparatory to seeding. Quite a number are now using Sweet Clover 
as a preparatory crop, before growing Alfalfa. Often it is practical to manure the ground with a good coat of well rotted manure and by doing this you are bound to make a greater success and secure larger returns. You cannot miss it by applying manure before seeding, as on nearly all soil better results are obtained.

If the land is quite fertile good results can be expected by seeding without any special preparation.

It is necessary to bear in mind not to get sour or wet land. If you are in doubt about your land containing acid, it might be well to test it, which is a very simple process. Secure some blue litmus paper from the druggist and take a handful of moist soil and work into a ball; place a strip of blue litmus in the middle and allow it to remain a short time; on removing, if the paper has changed to red, the soil is decidedly acid, but if only slightly pink the degree of acid is not so marked. If you find your soil of an acid nature it requires lime. Acid condition of the soil is corrected by using lime. Although a soil tonic, it is not a direct fertilizer, as many suppose. All legumes are benefited by proper liming and you can usually increase results by using lime; the degree of acidity of the soil serves as an indicator for the amount of lime needed. From 1,000 to 3,000 


\section{THE GROWING OF GOLD}

pounds per acre will be sufficient in most cases, but some of the Eastern States may require larger amounts. Lime may be applied with a manure spreader, or from a wagon with shovel. A broadcast endgate seeder may be used to advantage.

After you have decided on the field you intend to use for Alfalfa, it is then necessary to get it in proper condition for seeding. The process necessary to follow will depend quite largely on the crop preceding. In many sections where fall seeding is desirable it is well to have Alfalfa follow a small grain crop, or early potatoes leave the ground in good condition for seeding.

Spring seeding may follow most any crop, but it would be well to follow some cultivated crop that has freed the ground from weeds. One objection to spring seeding in the humid section is the weed proposition. It is well to secure a field as free from weeds as possible, as better results will be obtained. 


\section{THE GROWING OF GOLD}

CHAPTER III.

\section{INOCULATION AND FERTILIZATION.}

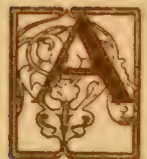

LL leguminous plants require inoculation to insure the best growth. This, however, does not mean that it is always necessary to inoculate before seeding, for in many cases the soil is already properly inoculated, so that very satisfactory results are obtained. Where Alfalfa or Sweet Clover has not been grown, it is impossible to tell whether the soil is inoculated or not, so on this account you are much surer of results by first inoculating the soil or seed before seeding. The expense of inoculation is not great and the increased results will many times pay for it. If there are no bacteria in the soil, a failure undoubtedly would be the result, while if the soil was only partially inoculated the Alfalfa would not do well and be sickly. On nearly all soil better results can be obtained by proper inoculating before seeding. It has been proven by many experiments that inoculation is required for best results, and it is not an expense to inoculate, but an investment that will much more than pay for itself the first season in the way of increased production. Besides, each following year you will be getting heavier crops, so it is to your 
interest to inoculate the soil and not take chances on seeding without.

There are two methods of inoculation, one known as the soil-transfer method and the other the pure culture. The inoculation by soil-transfer method is quite commonly practiced and is very satisfactory. This method is very simple and is not difficult to follow, although it is laborious and has one objection which should not be forgotten. That is to get soil which is free from noxious weeds, insect or plant enemies, for you might introduce some pest on your land which would be hard to exterminate.

In order to inoculate by the soil-transfer method, it is necessary to secure soil from a good, healthy Sweet Clover field or from the roadside where it may be found growing, or from an Alfalfa field. It requires about 200 to 300 pounds of soil to the acre, which should be scattered over the field just before seeding and after the soil is scattered it should be immediately covered by harrowing, for the sun's rays will kill the bacteria germ if left exposed for any length of time. This soil, if fine, can be sown broadcast by hand, or with an end-gate seeder, or it may be put on the ground with a manure spreader. Another way which might be very practical is to fasten a 


\section{THE GROWING OF GOLD}

long narrow box on the front of the harrow, with a slat bottom, leaving openings sufficiently large so that the soil may scatter out, thus distributing the soil and harrowing it in at the same operation. The soil could also be put in the field with a drill that has a fertilizer attachment. It is also suggested that it would be a good plan to take a small portion of the soil and mix with the seed at the time of sowing, but this is not necessary if the soil has been well distributed before seeding.

The pure-culture method is much more easily done and is giving excellent results, and is recommended both by the Department of Agriculture and the State Agricultural Colleges. It has the advantage of preventing the introduction of harmful weeds or pests on the farm and is much more easily secured.

There are several different places where the culture is manufactured, but the culture furnished by the A. A. Berry Seed Co. is equal to the best and the writer does not hesitate to recommend it to all who need to inoculate. This is what the manufacturer says about our Nitrogen Culture: "The cultures listed are guaranteed to be first-class in every respect. They are prepared by an expert bacteriologist, who follows accurately the formula set forth by the Govern- 


\section{THE GROWING OF GOLD}

ment; the purchaser is thus assured of receiving the best to be had."

Full directions come with each package, giving full instructions as to using it. The Culture is mixed with water, according to directions given with it, and the seed is moistened with the culture, so that each seed is affected, but care should be taken so as not to soak the seed. As soon as the seed is sufficiently dry it should be planted.

You should not wait any great length of time for the nodule bacteria will soon die. Seed which is treated should never be exposed to the rays of the sun when drying and should be covered immediately after seeding.

We have already mentioned the importance of manuring, but wish to emphasize the fact that you can get no greater returns from your manure than applying it on your Alfalfa field. It is not absolutely necessary to use manure, but a much heavier crop may be expected and you are also assured of being more successful in obtaining a stand. So do not feel that you are wasting your time when using manure preparatory to seeding. The richer the soil, the heavier is the yield. Richer soil increases the growth the same as plenty of water. It is true that Alfalfa will withstand much drought, but the heavy yields are 


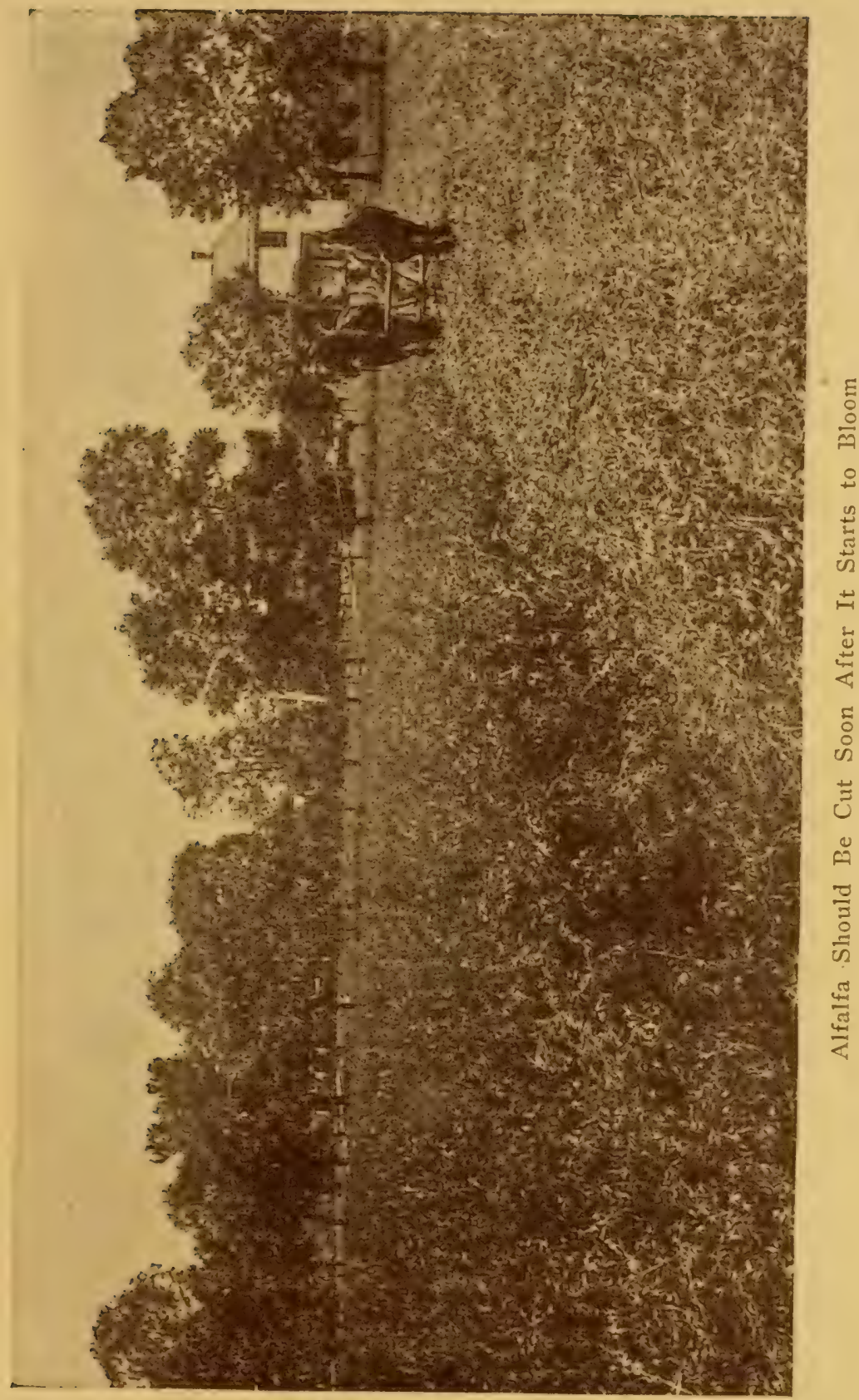




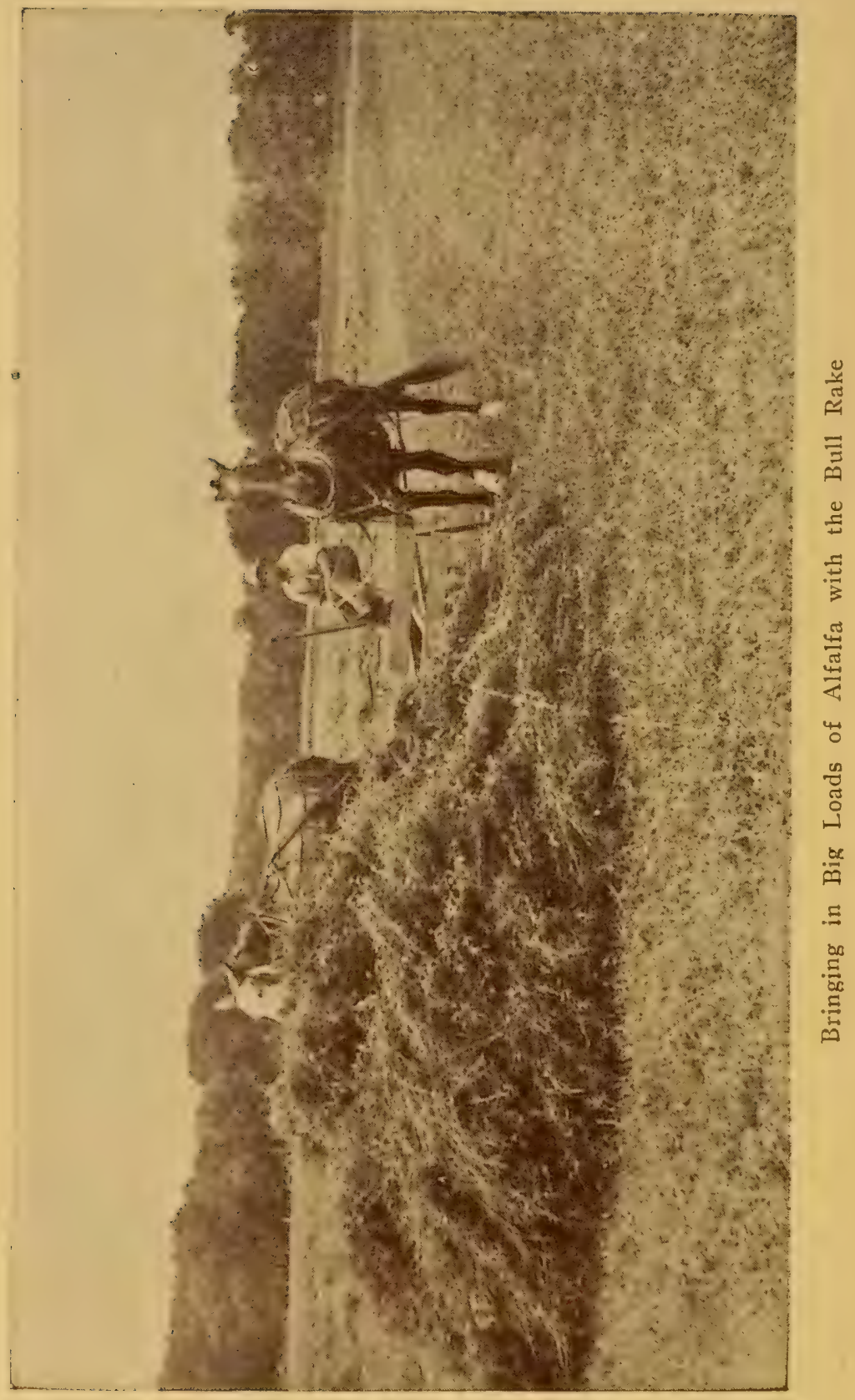


THE GROWING OF GOLD

secured when supplied with plenty of moisture, either by nature or artificially. 


\section{THE GROWING OF GOLD}

CHAPTER IV.

\section{SEEDING OF ALFALFA.}

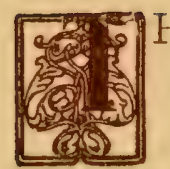

$\mathrm{HE}$ time of seeding Alfalfa must vary in different sections of the country, owing to the weather conditions and nature of climate. Spring seeding has been proven very successful throughout the corn belt and the Eastern States, and we believe more seeding is done in the spring than fall. In sections of heavy rainfall, it is doubtful whether spring seeding is advisable on account of the weeds. So early fall seeding would be preferable.

Alfalfa may be seeded in spring, with small grain in the same manner as Clover. The seed bed should be well prepared the previous fall or early in the spring. When seeding with a nurse crop, use a grain that may be removed early and the grain crop should be reduced about a half, so as not to smother out the Alfalfa. Better results can be expected from spring seeding by using a very light nurse crop and seeding about the last of April and then remove the nurse crop for hay in June. This keeps the weeds down and the Alfalfa should be up nicely, so that after the nurse crop is removed, it should have a start of the weeds. 


\section{TH.E GROWING OF GOLD}

Splendid results are obtained from spring seeding by sowing without a nurse crop. If this method is to be followed it is well to plow the ground in the fall or early in the spring and cultivate the ground from time to time, so that much of the weed seed will be destroyed before seeding. About May first the Alfalfa should be sown and as it is then warm the Alfalfa will soon start and if there is not too much rain the Alfalfa should get a start of the weeds.

In the corn belt seeding in this manner has given excellent results, especially in dry years. When Clover has been a complete failure on account of drought, Alfalfa has done well and makes a most excellent stand.

When fall seeding is practiced it usually follows a small grain crop. It is very important that the ground be plowed at once after the grain is cut and then harrowed until a perfect seed bed has been secured. It is best to plow shallow, as a more compact seed bed will result. We find that double discing the stubble is proving very satisfactory. When the ground is dry, discing might be easier done and more satisfactorily, as a good seed bed can be secured. The proper time for fall seeding is the latter part of August or during September. It is well to sow as early in 


\section{THE GROWING OF GOLD}

the fall as possible, so that the plant may become well rooted before freezing weather. There is danger of winter killing if sowed too late.

Experiments have proven that it is a little surer to summer fallow the ground and sow the last of July or the first of August, but this causes the loss of a crop one year, and the writer does not advise following this method on this account. Good results may be expected by seeding either in the spring or in the fall, after harvesting grain, if no time is lost in getting the ground ready. It is essential to put much work on the land and get as good a seed bed as it is possible to obtain.

The amount of seed required per acre varies somewhat and you will find different amounts recommended. It is not necessary to sow more than 15 pounds of our World Brand Alfalfa, as this makes a heavy seeding, and a less amount may be sufficient. If you have seed of low germination it would require more, but it is policy to get the best when seeding Alfalfa.

Good results can be expected by either sowing broadcast by hand, or by using a hand seeder. The Cyclone hand seeder can be recommended as a special broadcast hand seeder for sowing all kinds of grass seed. After sowing, harrow, so as to cover the seed; or the seed may be drilled if the ground is even and the seed can be covered 


\section{THE GROWING OF GOLD}

so as not to put part in too deep. The seed should be covered about one-half inch-not over an inch. When the seed is covered too deep the plant will be spindling and sickly and not nearly so vigorous as it would be if but lightly covered.

Alfalfa germinates very quickly and if sowed properly in a well prepared seed bed it will all be up in a week's time, providing there is sufficient moisture and weather is warm. You will be surprised at the rapid growth it makes and oftentimes early fall seeding will get a foot high before frost. 


\section{THE GROWING OF GOLD}

CHAPTER V.

CARING FOR ALFALFA.

aHEN Alfalfa is seeded in the spring without a nurse crop, it is well to go over the field several times during the summer, clipping the weeds so that they do not smother the young plants. The clipping of the Alfalfa stimulates the growth of the plant. As a rule, you cannot expect much of a crop the first season, although early seeding on a rich field producing a rapid growth might be cut for hay the last of August. It is best to leave a large growth on the ground as a cover during winter. The crop on the ground will hold the snow and there is much less danger of winter killing than when the ground is bare.

Fall seeding requires no special attention the first fall, as the entire growth should be left as a cover crop. The following year the crop should yield three or four cuttings. The first crop should be ready to cut about the middle of June and when cutting it should not be mowed too low.

The disc is resorted to by many to thicken and even a stand of Alfalfa. It is well to use a disc after the first year, provided conditions are favorable, but care should be exercised to prevent 


\section{THE GROWING OF GOLD}

harm. Where a stand is thin, the weeds, if not eradicated, will soon destroy the Alfalfa.

The report on cultivating Alfalfa, by Prof. Hughes, is no doubt one of the best methods of handling: "The ordinary disc has no doubt been used more generally for this purpose than any other implement, but it is not nearly so good as a spring-tooth harrow or the Alfalfa renovator. While independent plants sometimes develop from portions of the crown of the Alfalfa, which are cut off by the disc, this hardly happens enough to be of great value in thickening the stand, while the plant may be injured by presenting a favorable opening for fungus disease. Whether benefit is derived from cultivation with the disc is due to other factors than an increased number of plants.

"The spring-tooth harrow, constructed of stiff springs, ended in small shovels, which are in continual vibration as they pass through the soil, is very effective in removing the weeds and grass, without in any way injuring the Alfalfa plants, as the weeds and grass are shallow-rooted and easily pulled up. Alfalfa roots penetrate many feet in the soil and when the narrow shovel of the spring-tooth harrow comes in contact with them it springs far enough to one side to pass the plant without injuring it. 


\section{THE GROWING OF GOLD}

"Sometimes the desired results are not secured from cultivation, because the work is not thorough enough. Many times the man doing the work is afraid of injuring the Alfalfa. We have cultivated Alfalfa until it seemed that no living plant could remain, and until the field appeared to be a perfectly prepared seed bed, yet the old crowns threw up new shoots and before frost the Alfalfa stood 14 inches high, 4 inches higher than other Alfalfa in the same field which had not been cultivated. This increased vigor was due in part to the fact that where the Alfalfa was not cultivated the grass was crowding it badly, while on the cultivated portion no weeds were to be seen. Ordinarily we would not recommend so severe treatment as this, but we do wish to impress the necessity of thorough cultivation."

In the corn belt, blue grass is liable to be found troublesome in the Alfalfa field, and this can be successfully overcome by thorough cultivation, as above described.

Some Alfalfa fields after the first year seem to be sickly and die out. This may be due to various causes, but if the land is properly inoculated the cause may be due to lack of lime or fertility. Much benefit may be derived from top dressing the Alfalfa field with a good dressing of well rotted manure that contains no weed or grass 
seed. Usually manuring the fields helps the growth and secures greater yields of hay.

The life of an Alfalfa field depends quite largely on how well the plant succeeds. Alfalfa is a perennial plant and some fields have been known to exist fifty years, but as a rule it is advisable to rotate crops and as Alfalfa is a splendid fertilizer, it is well to change the field as soon as better results might be expected, by plowing up and planting to some other crop. It is well to have some other field of Alfalfa coming on, as no one can well afford to be without the crop. After growing it successfully, it requires no urging to have reseeding done. Every successful Alfalfa grower is very enthusiastic and some become "Alfalfa cranks," so to speak. 


\section{THE GROWING OF GOLD}

CHAPTER VI.

\section{HARVESTING OF ALFALFA.}

G $F$ all the various points to study in the growing of Alfalfa, none is of more importance than the cutting and curing of the hay. Upon the proper execution of these two things depends largely the value which may be obtained from your Alfalfa field.

The general rule is to cut Alfalfa just as it is coming into bloom. Feeding experiments show that the feeding value is the highest when it is cut at the time it begins to bloom. It is well to cut Alfalfa when you notice the basal shoots starting which are to form the growth of the new crop. By cutting at this time the new crop starts immediately. So no time is lost and larger yields are secured. If dry weather has prevented the basal shoots from starting, cutting should not be delayed so as to lose the value of the hay.

Alfalfa hay should be gotten up without rain, if possible, for the rain turns it black and much of the feeding value is lost. In the West where there is little rainfall during harvest time, there is not much difficulty experienced in getting the hay up without rain. There they often start 


\section{THE GROWING OF GOLD}

mowing in the morning, and can put the hay in the windrows in the afternoon and the following day commence stacking. In the humid zone more difficulties are encountered, and it is often hard to get the first cutting up without suffering some loss on account of rain.

The quicker the crop can be cured and the less handling it receives, the better the quality of hay. The leaves shatter very easily when wet, and as the greatest per cent of nourishment is in the leaves of Alfalfa hay, so the least possible loss of them should be avoided. It is well to put Alfalfa in the windrow just as soon as it becomes well wilted or about half cured, and either allow it to finish curing in the windrow or in the cock.

Alfalfa hay can be stacked much damper than is supposed, without risk of spoiling in the stack. It may turn black if stacked too green, but it is better to put in stack a little too green than to have it suffer on account of rain, as it will contain greater feed value. When the side-delivery rakes are used, it is much easier to cure Alfalfa. It can be put in small windrows as soon as it is well wilted, and hauled to the barn.

It is much better to put Alfalfa hay under cover. If there is not sufficient barn room and it is necessary to stack, care should be used in 


\section{THE GROWING OF GOLD}

stacking and the top of the stack should be covered with slough hay or with some crop that will shed water. Alfalfa hay is too valuable to lose any by careless handling and the entire crop should be preserved with the least possible loss.

Alfalfa does not have as great a value as a pasture crop as it does a hay crop, although it is used with great success for pasturing all kinds of stock. An Alfalfa field should not be pastured the first year and at no time should it be pastured too closely. It is much better to have the field under-stocked than over-stocked.

There is some danger in pasturing sheep and cattle on Alfalfa, as it is liable to cause bloat. This danger is much increased when pasturing young Alfalfa or Alfalfa on moist soil which makes a rapid growth. Animals should not be turned on Alfalfa when wet or the stock is very hungry. With sheep and cattle the Alfalfa should be well advanced towards blooming.

Alfalfa makes excellent pasture for hogs, and no hog raiser should be without it. Best results might be obtained when pasturing hogs by having the field divided, allowing one field to be pastured off while the other was making new growth. By changing from one field to the other 


\section{THE GROWING OF GOLD}

the Alfalfa will do much better and the production will be greatly increased.

Alfalfa seeds in paying quantities only when there is a shortage of moisture. Alfalfa seed is produced quite generally throughout most of the Western states, but in the rain belt there is no seed crop except in a dry year. As a rule the second crop is cut for seed, but in some sections the third crop is saved in preference. When allowed to seed, the Alfalfa should be cut when about three-fourths of the pods have turned brown. The crop may be harvested in the same manner as Clover or a self-binder may be used to advantage. Alfalfa can be threshed with an ordinary grain thresher, but a huller will do much better work. The yields run from 2 to 6 bushels of seed per acre and instances of 10 to 12 bushels per acre have been reported. 


\section{THE GROWING OF GOLD}

CHAPTER VII.

\section{SCIENTIFIC FEED VALUE.}

07 OU will find Alfalfa recognized as the King of forage plants, as there is no question about its great feeding value. The value of Alfalfa as a feed is well handled by Bulletin No. 137, issued by the Iowa Agricultural Experiment Station and is herewith given in full: "Alfalfa has a great feeding value, either as hay or pasture. It has a relative high content of digestible protein.

All crops other than the legumes contain a relatively high per cent of carbohydrates, and a relatively low per cent of protein-the stuff feeders are forced to buy as concentrates to balance rations. Alfalfa, on the contrary, has a relatively high per cent of protein and is easily digested, qualities that cannot be over-estimated.

TABLE IV.

The Average Composition of Alfalfa Compared with Other Crops.

\begin{tabular}{l|c|c|c|c|c|c}
\hline Crop & Water & Ash & $\begin{array}{c}\text { Crude } \\
\text { Protein }\end{array}$ & $\begin{array}{c}\text { Crude } \\
\text { Fiber }\end{array}$ & $\begin{array}{c}\text { Nitrogen } \\
\text { Free } \\
\text { Extract }\end{array}$ & Fat \\
\hline Alfalfa $\ldots .$. & 8.1 & 8.8 & 14.6 & 28.9 & 37.4 & 2.1 \\
Red Clover. & 15.3 & 6.2 & 12.3 & 24.8 & 38.1 & 3.3 \\
Timothy .. & 13.2 & 4.4 & 5.9 & 29.0 & 45.0 & 2.5 \\
Corn ...... & 10.6 & 1.5 & 10.3 & 2.2 & 70.4 & 5.0 \\
Oats … & 10.4 & 3.2 & 11.4 & 10.8 & 59.4 & 4.8 \\
Corn Stover & 40.5 & 3.4 & 3.8 & 19.7 & 31.5 & 1.1 \\
Oat Straw. & 9.2 & 5.1 & 4.0 & 37.0 & 42.4 & 2.3 \\
\hline
\end{tabular}




\section{THE. GROWING OF GOLD}

Alfalfa hay is especially valuable to the dairyman, though it is also known to give excellent results with all classes of live stock. It is especially valuable where a rapid development of muscle and bone is essential, as with brood sows, young pigs and steers.

\section{TABLE V.}

The Food Value per Average Acre and Other Crops Based on the Average Composition and the Average Yield for the State for 1909 and 1910.

\begin{tabular}{|c|c|c|c|c|c|}
\hline Crop & Ash & $\begin{array}{c}\text { Crude } \\
\text { Protein }\end{array}$ & $\begin{array}{l}\text { Crude } \\
\text { Fiber }\end{array}$ & $\begin{array}{c}\text { Nitrogen } \\
\text { Free } \\
\text { Extract }\end{array}$ & Fat \\
\hline Alfalfa $\ldots \ldots \ldots$ & 488 & 808 & 1600 & 2070 & 116 \\
\hline Red Clover*.... & 155 & 307 & 620 & 950 & 82 \\
\hline Timothy* ...... & 110 & 147 & 722 & 112 & 62 \\
\hline Corn Total..... & 102 & 293 & 456 & 2119 & 127 \\
\hline Grain .......... & 31 & 215 & 458 & 1464 & 104 \\
\hline Stover ........ & 70 & 79 & 411 & 655 & 23 \\
\hline Oats Total. & 135 & 195 & 852 & 1450 & 94 \\
\hline Grain $\ldots \ldots \ldots$. & 32 & 114 & 109 & 598 & 48 \\
\hline Stover ........ & 102 & 80 & 743 & 852 & 46 \\
\hline
\end{tabular}

"Assuming yield to be that given for "Tame Hay."

Considering the average yield of various crops for those years in which Alfalfa data are available in Iowa, Alfalfa produced 5.5 times as much protein per acre as Timothy, 4 times as much as Oats, 2.75 times as much as Corn, and 2.6 times as much as Red Clover.

As a pasture for hogs the animal husbandry section of the Iowa Agricultural Experiment Station reports a net profit of $\$ 184.92$ per acre from Alfalfa, the hogs selling at 6 cents and the corn fed costing 49 cents for 56 pounds of 


\section{THE GROWING OF GOLD}

grain on the cob. And this when an acre of blue grass handled in the same way gave a profit of but $\$ 97.23$.

TABLE VI.

Showing the Average Per Cent Digestibility of Alfalfa as Compared with Other Crops.

\begin{tabular}{|c|c|c|c|c|c|}
\hline Crop & $\begin{array}{c}\text { Dry } \\
\text { Matter }\end{array}$ & Protein & $\begin{array}{l}\text { Crude } \\
\text { Fiber }\end{array}$ & $\begin{array}{l}\text { Nitrogen } \\
\text { Free } \\
\text { Extract }\end{array}$ & Fat \\
\hline Alfalfa $\ldots \ldots \ldots \ldots$ & 62 & 72 & 47 & 72 & 43 \\
\hline Red Clover......... & 57 & 58 & 54 & 64 & 55 \\
\hline${ }_{\text {Corn }}$............ & $\begin{array}{l}55 \\
91\end{array}$ & $\begin{array}{l}48 \\
76\end{array}$ & $\begin{array}{l}50 \\
58\end{array}$ & $\begin{array}{l}62 \\
93\end{array}$ & $\begin{array}{l}50 \\
86\end{array}$ \\
\hline Oats $\ldots \ldots \ldots \ldots \ldots$ & 70 & 77 & 31 & 77 & 89 \\
\hline Corn Stover..... & 57 & 36 & 64 & 59 & 67 \\
\hline Oat Straw....... & 48 & 33 & 54 & 46 & 36 \\
\hline
\end{tabular}

The table on the actual feeding value of Alfalfa in the Government Bulletin will be of interest and is worth your study, and is given as contained in Farmer's Bulletin 339.

"The following table indicates the actual feeding value of eight different kinds of feed, based on the amount of digestible nutrients contained in them. These values are calculated from the figures given in the table just preceding. The value per pound assigned as the basis of calculation are protein, $\$ 0.06774$; carbohydrates (starches, etc.), \$0.0064; ether extract (fat), $\$ 0.0112$. These figures are merely relative, as the prices of the food elements vary in the different sections and from year to year. It will 


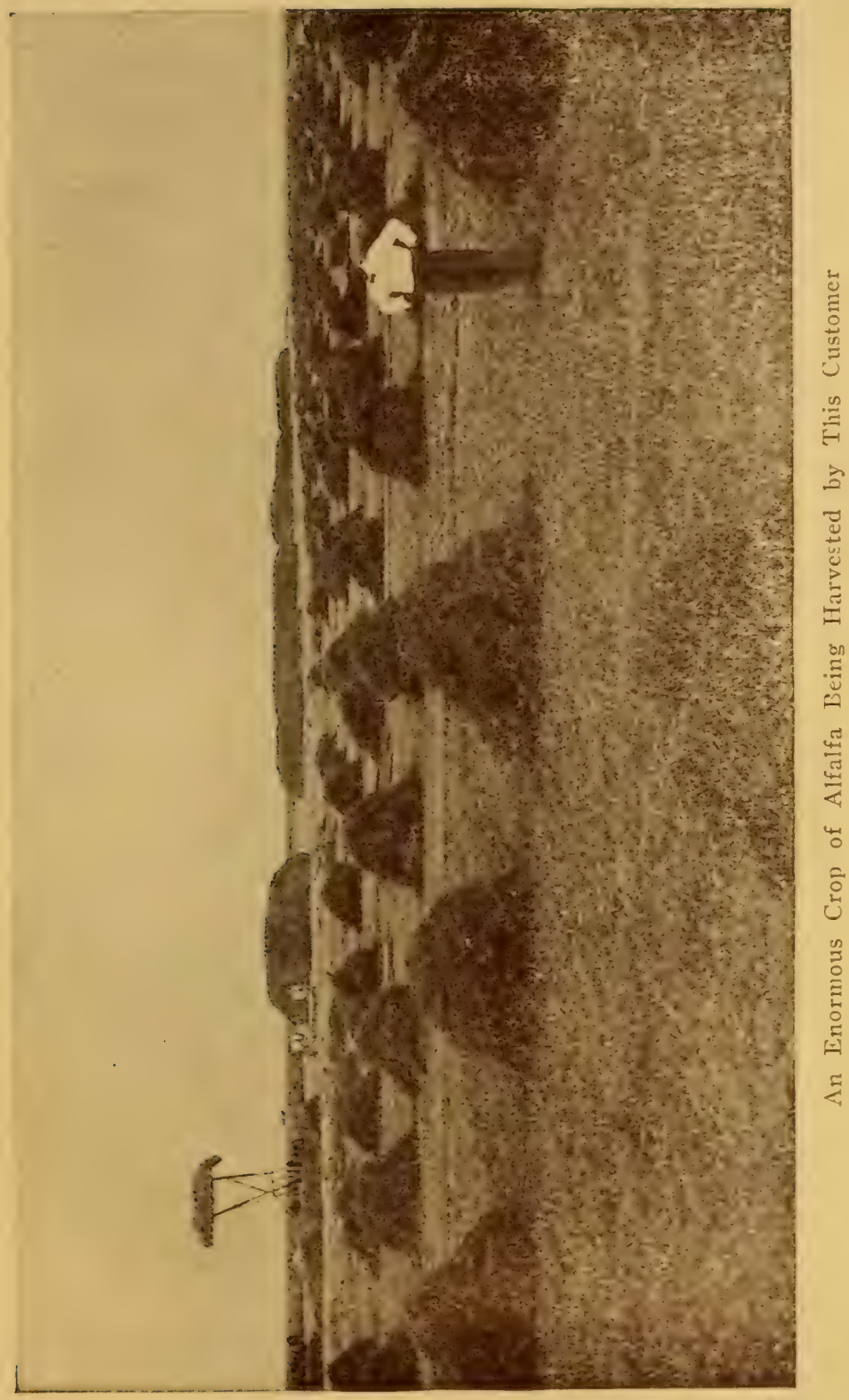




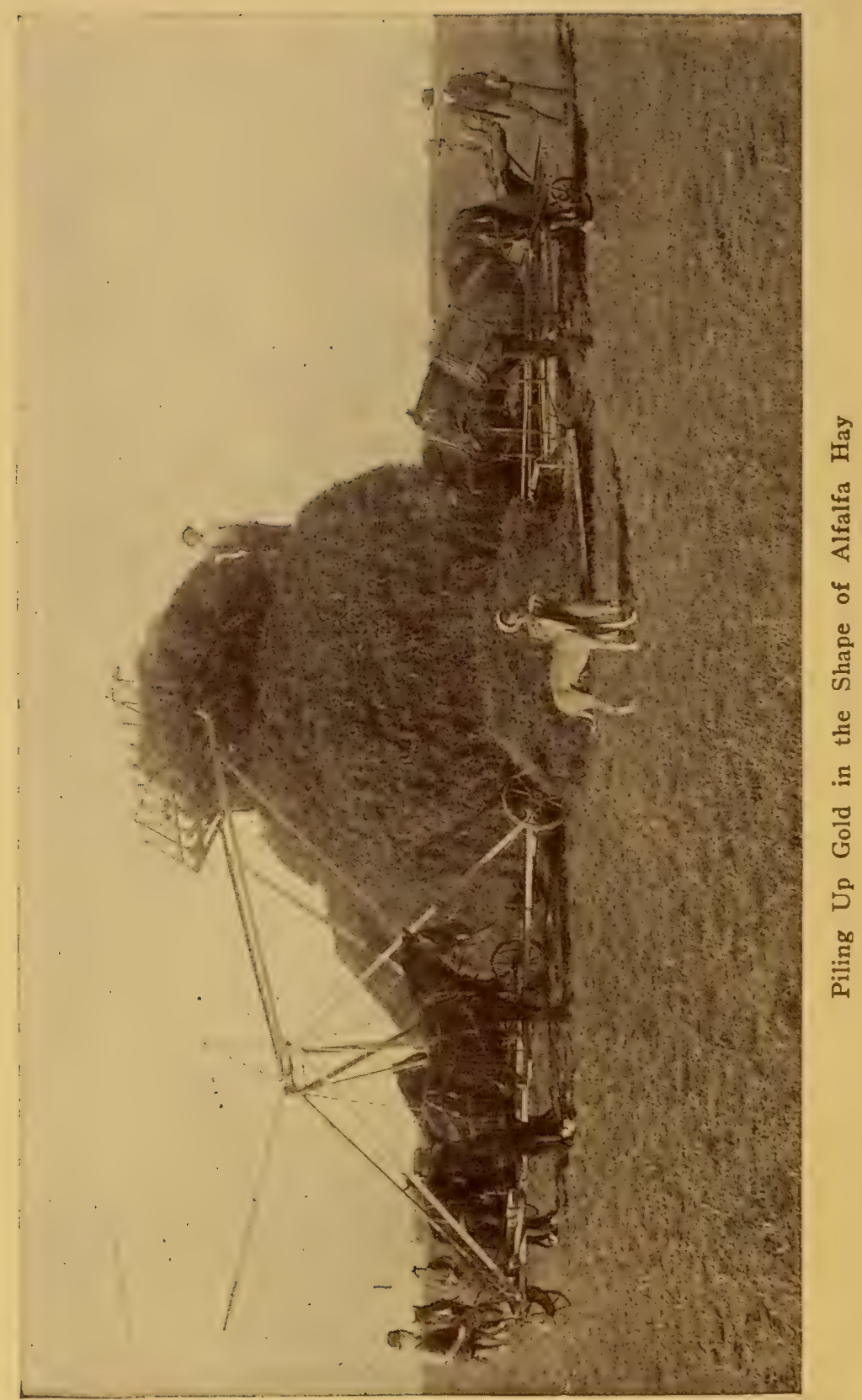




\section{THE GROWING OF GOLD}

be noted that the value of Alfalfa hay is slightly more than double that of Timothy."

Actual Feeding Value of Different Feeds Based on Amounts of Digestible Nutrients.

\begin{tabular}{|c|c|c|c|}
\hline Feed & $\begin{array}{c}\text { Value } \\
\text { Per Ton }\end{array}$ & Feed & $\begin{array}{l}\text { Value } \\
\text { Per Ton }\end{array}$ \\
\hline 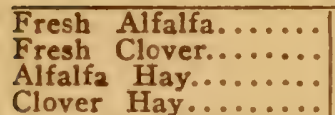 & $\begin{array}{r}\$ 7.00 \\
5.00 \\
20.16 \\
14.12\end{array}$ & $\begin{array}{l}\text { Timothy Hay...... } \\
\text { Cow Pea Hay..... } \\
\text { Wheat Bran..... }\end{array}$ & $\begin{array}{r}\$ 9.80 \\
19.76 \\
22.80 \\
20.16\end{array}$ \\
\hline
\end{tabular}

We are giving a table figured on estimated yields per acre and the actual test of protein in each kind of plant and its comparative values per ton. We have taken as our basis Timothy hay at $\$ 5.00$ per ton and have estimated the yield on Alfalfa at 5 tons per acre, which is conservative.

\begin{tabular}{l|c|c|c|c|c}
\hline \multicolumn{1}{c|}{ Kind } & $\begin{array}{c}\text { Yield } \\
\text { per A. } \\
\text { Tons }\end{array}$ & $\begin{array}{c}\text { Per Cent } \\
\text { Protein } \\
\text { Hay }\end{array}$ & $\begin{array}{c}\text { Pounds } \\
\text { Protein } \\
\text { Per Ton }\end{array}$ & $\begin{array}{c}\text { Pounds } \\
\text { Protein } \\
\text { per A. }\end{array}$ & $\begin{array}{c}\text { Value per } \\
\text { A. Based } \\
\text { on Protein }\end{array}$ \\
\hline Alfalfa $\ldots . . . .$. & 5 & 14.6 & 292 & 1460 & $\$ 61.86$ \\
Red Clover.... & $21 / 2$ & 12.3 & 246 & 615 & 26.06 \\
Timothy $\ldots . . .$. & 2 & 5.9 & 118 & 236 & 10.00 \\
Oat Straw..... & 112 & 4.0 & 80 & 120 & 5.09 \\
\hline
\end{tabular}

This table speaks volumes and shows the great value of Alfalfa hay as a protein crop. Protein feeds are the ones sought after by the dairyman, cattle raisers and growers of stock. Proteins come high when it is necessary to purchase them in concentrate feeds such as chop, bran, oilmeal, tankage, etc. 


\section{THE GROWING OF GOLD}

Don't fail to study these tables and see for yourself the great value of Alfalfa as a feed. There is no plant that will make you more money than growing Alfalfa for feeding purposes. It cannot be surpassed and is a great money maker. 


\section{THE GROWING O,F GOLD}

CHAPTER VIII.

\section{ALFALFA THE MONEY CROP.}

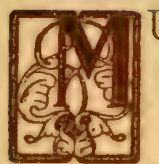

$\mathrm{UCH}$ has been written on the value of Alfalfa, but as yet the great value of this plant has not been realized by the average farmer. Alfalfa growing is just in its infancy and greater profits are to be realized from this plant from now on than ever before. Alfalfa will be a much more profitable crop for the Eastern farmer than it has ever been for the Western farmer, as the market is near at hand and the entire crop can be turned into profit without paying long freight hauls and various other expenses.

Every dairyman should be a large grower of Alfalfa hay as he cannot afford to be without it. There is no crop that will bring larger returns for him and there is no feed that will do so much good as Alfalfa hay. The Government Bulletin reports: "Experiments made by the Tennessee Agricultural Experiment Station in regard to the replacing of grain with Alfalfa in ration for dairy cows indicated that $1 \mathrm{I} / 2$ pounds of Alfalfa will replace 1 pound of wheat bran. The test showed with Alfalfa hay at $\$ 10.00$ a ton and wheat bran at $\$ 20.00$ the saving 


\section{THE GROWING OF GOLD}

effected by substituting Alfalfa for wheat bran is $\$ 2.80$ for every 100 pounds of butter and 20 cents for every 100 pounds of milk." When a crop can be grown successfully that will produce such a saving in feed, how can a successful dairyman be without it?

Alfalfa is just as valuable to the stock grower as it is to the dairyman, and it behooves the farmer who has been constantly growing corn to rotate the land and start growing Alfalfa. Much larger results may be expected from an acre of Alfalfa than an acre of corn as a money crop, besides the great advantage of building up the land and increasing its value, rather than depleting the soil and lowering its value as with constant corn growing.

The Government Bulletin reports: "The Utah Agricultural Experiment Station conducted an experiment extending over a period of five years to determine the quantity of beef produced to the acre from Alfalfa hay cut in the different stages of maturity. It was found that hay cut when in full bloom produced 562 pounds of beef annually to the acre, while that cut in early bloom produced 706 pounds. The hay that was not cut until half the blooms had fallen produced only 490 pounds of beef to the acre. At the Nebraska Agricultural Experiment Station 2.41 
pounds of beef was produced daily on a full ration of corn and Alfalfa, while only 1.48 pounds were produced by a ration of corn and prairie hay.

These experiments are convincing proof of the value of Alfalfa hay to the cattle feeder, and there is no crop that works so well with corn as Alfalfa. Alfalfa hay supplies the protein that is so much needed in the corn belt, and it can be grown so much cheaper than it can be secured any other way. It is essential to study economic conditions and produce beef as cheaply as it can possibly be produced, if you wish to make money in the growing and fattening of cattle.

The value of Alfalfa as a hog feed cannot be over estimated and should be considered by every hog grower. The greatest value no doubt is secured from the pasture, although Alfalfa hay makes excellent feed during the winter months. It is relished very much and is excellent for brood sows, as they enter the spring farrowing season in much better condition. The value of Alfalfa as a hog feed is given in the Government Bulletin as follows: "At the Kansas Agricultural Experiment Station it has been shown that an acre of Alfalfa produced 776 pounds of pork during the season. This calculation was made 


\section{THE GROWING OF GOLD}

by deducting the probable gain due to the small ration of grain fed in connection with the pasturage. In another experiment it was shown that for every bushel of Kaffir Corn meal and 7.83 pounds of Alfalfa hay the hogs made a gain of 10.88 pounds. When the Alfalfa was withheld from the ration the gain was only 7.48 pounds for each bushel of grain fed.

Alfalfa is a feed that is good not only for cattle and hogs, but it is equally as valuable for sheep, horses, or poultry. It is a crop that is in demand on every farm by all kinds of stock.

After reading the reports given on Alfalfa, it would seem that it would take no urging to have every farmer sowing Alfalfa, but such is not the case. Farmers are a good deal like sheep in this respect, and it is hard to get one to take the lead, but after one starts and makes a success, the balance will soon follow. There are now progressive farmers in nearly every neighborhood who are starting the growing of Alfalfa, and in a few years the entire neighborhood will be growing it. Why not be the first one to start growing Alfalfa in your section if it has not been grown? You could do your country and neighbor no greater service and at the same time you would be adding great value to your farm. 


\section{THE GROWING OF GOLD}

The growing of Alfalfa is certainly "The Growing of Gold," as it brings a threefold income. When you seed your field to Alfalfa, you are planting a crop that will in all probability bring you a larger net income than you could expect to realize from any other crop. It is not uncommon to get a yield of from 4 to 6 tons of hay per acre, valued from $\$ 10.00$ to $\$ 20.00$ per ton. We have many customers who have reported that the crop from one year was over $\$ 100.00$ per acre. While you are growing a crop that is bringing you from $\$ 50.00$ to $\$ 100.00$ per acre, you are also adding much wealth to your farm. Alfalfa is a great fertilizer, and when you stop growing it and wish to grow some other crop your land has increased in fertility until it is much more valuable. You have also added value to your farm, as real estate value increases wherever Alfalfa grows. The United States Department of Agriculture says: "In addition to the hay and seed crop, Alfalfa adds $\$ 100.00$ to the value of every acre on which it grows." If you want to sell your farm, seed it to Alfalfa and you will have no difficulty, and the longer you wait before selling the more you will realize. Many farms have doubled in value by making no other improvement than growing Alfalfa. The value of 


\section{THE GROWING OF GOLD}

Alfalfa is appreciated in all sections and no matter where located, you can add great wealth to your farm by using Alfalfa seed.

Don't think because you have not grown Alfalfa that you cannot grow it successfully. Be willing to give it a fair trial for you can make a success of it just the same as thousands and thousands of other farmers. It is stated by good authority that Alfalfa will grow on 99 per cent of the farms in the United States, so we know of no crop that can be grown in all sections so successfully. Read this book carefully and by using judgment, there is little chance of you failing to make a success. Correspondence is always welcomed by the A. A. Berry Seed Co., and if you have any particular questions to ask or desire special information, be free to write us and it will afford us pleasure in helping you along to greater success in the growing of Alfalfa. 


\section{THE GROWING OF GOLD}

CHAPTER IX.

\section{THE BEST ALFALFA SEED.}

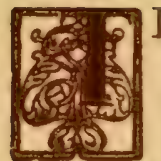

HE importance of good seed is a subject that should have the careful thought and consideration of every person who contemplates seeding Alfalfa. There is a vast difference in the seed offered, and as results depend quite largely on the seed used it is necessary to use care and precaution in securing seed.

It has been proven by different experiments that northern-grown seed is more hardy than southern stock and it is not advisable to get seed too far south. We have found that nonirrigated Nebraska-grown seed is unusually hardy and is giving the most satisfactory results of any seed we have handled and the writer does not hesitate to recommend it for all sections. We have many customers throughout South Dakota, Minnesota, Wisconsin and Eastern states, who are using this seed and find it extremely hardy and giving excellent results. The Montana seed is considered good if it is true to name, but it has been found that much of the so-called Montana seed offered by the large wholesale seed companies and handled by 


\section{THE GROWING OF GOLD}

retail merchants is not grown in Montana and is not what it should be. This is also true of the Grimm Alfalfa and some unscrupulous dealers are selling Grimm Alfalfa simply because there is a call for it and a fancy price can be secured. As yet, the true Grimm Alfalfa is only offered in a limited way, as the price is prohibitive for the pure stock. Excellent results can be obtained without using the Grimm Alfalfa and it is not advisable to try to secure it until later, when the seed is plentiful and prices more reasonable.

The Turkestan Alfalfa is demanded by many of the Northern growers and by Western customers who are located in a high altitude. The pure Northern Turkestan seed comes from a semi-arid region and is recommended very highly for the non-irrigated portion of the West and for high altitudes. It is very hardy and is proving an excellent variety, but it is not considered quite equal to the common American Alfalfa for the humid section.

Foreign Alfalfa seed is being offered in the United States very freely by all large wholesale seed companies, who import many carloads, as the price is about $\$ 3.00$ per cwt. less than domestic seed. This seed is sold to consumers by the local dealer who handles seed, so it is to 


\section{THE GROWING OF GOLD}

your interest to be careful about buying your seed. In most cases you will be surer of getting high grade seed by sending to a good reliable mail order house, which builds up its business on the quality of seed supplied.

The A. A. Berry Seed Co. takes great pride in being able to offer their customers the very best Alfalfa seed at right prices, and anyone who needs seed can depend on the quality being as represented. We buy our Alfalfa seed direct from the grower and can supply seed which is true to name on which you can absolutely depend. We deal extensively in Alfalfa and are in position to furnish the best grade of seed at a lower price than is asked by many competitors for inferior seed. Our World Brand Alfalfa is the grade to buy and you cannot make a mistake in buying your seed if you can secure this grade. It is sold subject to either State or Government test and there is no seed that will give better results. Don't use poor seed at any price, and on the other hand, don't pay an exorbitant price for seed that does not test so well as our World Brand. Always compare our prices and samples before buying. 


\section{WHAT OTHERS SAY.}

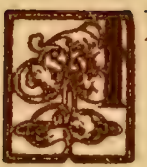

$\mathrm{N}$ concluding this little booklet, we are going to give some practical letters received from different customers who have made a success of growing Alfalfa. These letters should be helpful to our readers, as it should give them more courage and the utmost faith in the Alfalfa crop. What is being done by others can be done by you, if you apply the same energy and work for the same results.

\section{A Nobrakka Customer Gives Inis Mothod.}

Gentlemen:

Dorchester, Neb.

I am pleased to give you the results of the "World Brand" Alfalfa Seed which I bought of you last year. Have several different pieces of Alfalfa, but the soil is nearly the same, so I tried 15 acres which had been in oats and harvested in 1912. On August 5, 1912, this aioresaid 15 acres was plowed 4 inches deep and harrowed. About August 20 to 22, 1912, we used the disk thoroughly and harrowed it again, and used the seed drill for seeding. using only eleven pounds of seed per acre.

I have just finished cutting aforesaid 15 acres of Alfalfa. Am frank to say that it is the nicest and heaviest crop I have seen, getting more than one ton of hay per acre at first cutting. I do not have worn out land, but my opinion is to prepare the land for Alfalfa the same as prepared for garden; using the seed drill and sowing the best seed obtainable. "The best is always the cheapest." I have been one of your customers for a good many years, in buying all kinds of Grass Seed, Wheat and Potatoes, and have found out that I have no reason to look for a better seed company. I believe your satisfied customers are your best recommendation and advertisement. Yours truly,

E. C. SEMLER. 


\section{THE GROWING OF GOLD}

\section{LETTER FROM A PRACTICAL GROWER IN SOUTH DAKOTA.}

\section{Gentlemen:}

\section{Aberdeen, South Dakota.}

In reply to yours of June 10th will state that $I$ have at present thirty acres of alfalfa. Seven acres I sowed seven years ago this spring, eight acres six years ago this spring and fifteen acres a year ago this spring. Would advise plowing the land as early in the fall as convenient, cultivating the same so as not to allow any weeds to seed, and also making it as even as possible. In the spring I would disk it and drag it until just after corn planting, then I would seed it with either broadcast or by drilling, using from six to ten pounds of seed per acre. I have broadcasted mine, using ten pounds. This year I seeded fifty-five acres; forty acres about nine pounds to the acre and fifteen acres ten pounds to the acre. If the land is properly prepared there is no trouble about growing Alfalfa in this section.

Yours very truly,

ISAAC LINCOLN.

\section{THIS PARTY INCREASES HIS ACREAGE.}

\section{Dear Sir:}

Kalona, Iowa.

The Alfalfa seed I got from you last spring grew fine. I would like for vou to send me samples and prices on some more seed of the very best grade of Alfalfa, as I am going to sow some this fall. Yours truly,

HENRY BURKLEY.

\section{GOOD SUCCESS IN MONTGOMERY COUNTY.}

\section{Dear Sirs:}

Red Oak, Iowa.

In reply to your letter inquiring about what success I had with the Alfalfa Seed I got of you last fall. The seed was good as I ever seen, and I got a good stand. I plowed my ground about 6 inches deep, and disked and harrowed several times till I got it in good condition, then sowed the seed and sun a plank over it twice.

L. N. SMITH.

MINNESOTA CUSTOMER REPORTS OUR SEED PROVES BEST.

Gentlemen:

Morgan, Minn.

What are your prices on Alsike Clover and Alsike and Timothy mixed, such seed as we got last spring. The Alfalfa we got from you is surely fine if it will only stand the weather. We bought seed, that is Alfalfa seed, from Kansas, Montana, North Dakota. Minnesota and your house, but your seed was the best and cleanest. We had seed tested at the Minnesota Experiment Station. C. B. HUSCHKE. 


\section{THE GROWING OF GOLD}

\section{ALFALFA DID FINE IN ILLINOIS.}

Dear Sirs:

Sheffield, Ill.

Yours of recent date received and would say $I$ had a splendid stand of Alfalfa from the seed I bought from your firm.

I plowed two acres of oat stubble ground in August and hauled four 60 bushel loads of sweet clover soil on them, disked and harrowed, sowed the seed and harrowed several times. We had a good rain the next day and the Alfalfa came up splendidly. Yours truly,

EDWARD HARVEY.

\section{A VERY PRACTICAL LETTER FROM AN IOWA GROWER. \\ Massena, Iowa.}

Gentlemen:

Your request for my experience in raising Alfalfa at hand. I am pleased to state that I have had very good success indeed, much better than I hoped to have. I have been growing it for the last five years and have purchased all my seed of you and I have never failed to get a fine stand. I sow in August not later than the 15 th or 20 th on ground from which I have taken a crop of winter wheat. I double disk the ground as soon as I can get the wheat off, then plow. I double disk again and harrow, then sow broadcast from 15 to 20 pounds of seed per acre and harrow once. I have never used any commercial inoculation of any kind. I try to cover all the ground I intend to sow with manure from the sheds which is hauled on my winter wheat in the winter and early spring.

After the first year I cut from three to four times a year, owing to the season. I now have about 75 head of hogs running on a six acre field of it, and I consider it the best hog pasture there is. I cut a fair crop off this field about the first of June and it stands about a foot high now. I find it much easier to cure than clover and makes the finest hay in the world. I can't understand why every farmer in Southwestern Iowa don't grow it, as it is easily grown and will stand the dry weather better than almost any other grass.

Please send me samples and prices on seed, as I expect to sow some this fall again. Very truly,

E. E. GRIMES.

\section{DIFFERENT METHOD FOLLOWED BY THIS PARTY.}

\section{Gentlemen:}

Elbon, So. Dak.

In sowing Alfalfa, my preierence is for ground cultivated the previous year to potatoes or corn, which I disk in early spring and seed about May 1st after another disking, about 6 pounds per acre, and harrow lightly. But have had good success with spring plowing when followed by rains to settle the ground. On dry upland we have had good success drilling in rows 3 


\section{THE GROWING OF GOLD}

feet apart, about 2 pounds of seed per acre, and give it an occasional cultivation. This is mostly for the purpose of raising seed, but often get a first cutting for hay.

E. A. MORRISON.

\section{ALFALFA SHIPPED BETTER THAN SAMPLE.}

\section{Gentlemen:}

Laporte, Ind.

If the Alfalfa Seed which I bought from you had not tested up to your agreement you certainly would have received a vigorous kick from me and the seed back, but as it tested much better than the sample which you sent I think it only fair to advise you. Therefore, I am enclosing, herewith, the copies received by me from the State Agricultural College showing the test made of the sample before buying and also of the seed received. You will see that the seed you shipped me was much better than the sample sent before buying. The sample you sent before buying contained 98.55 of pure seed, while the seed you shipped after buying contained 99.6, for which I thank you. Cordially yours,

DAVID H. REEDER.

\section{SAVED MONEY BY PURCHASING SEED FROM US.}

\section{Dear Sir:}

Braymer, Mo.

I received your shipment of $20 \mathrm{lbs}$. of Alfalfa and $13 / 2$ bus. of Alsike and Timothy mixed and I want to say that it is the finest and cleanest seed I ever saw. 1 saved from three to four dollars by sending to your firm.

\section{RUSSELL ROBERTS.}

\section{PROF. HOLDEN URGES EVERY FARMER TO GROW ALFALFA.}

Mr. Holden says: "Alfalfa is destined to revolutionize agriculture in the United States. It is not difficult to grow. It is today grown on the borders of the civilization in the far Canadian north; it is grown in the southern tropics and from far east to west around the world. It will readily adapt itself to almost any character of soil or climatic condition. In the western states, alfalfa is successfully grown on mountain ranges in Montana and Colorado, nearly eight thousand feet above sca level. It is true that alfalfa will become a general farm crop in the United States in time. It will drift in by gravity.

"Twenty years from now, everyone will wonder how we got along without alfalfa and why we did not recognize its great value sooner.

"Many of the attempts in the past to grow alfalfa have failed, but, with our present knowledge of the requirements of the crop, there will be little, if any, more trouble in securing a stand of alfalfa than of clover. Alfalfa can be grown on your farm. Alfalfa is the cheapest source of protein. When wheat 
bran is worth $\$ 22.00$ per ton, good alfalfa hay is worth from $\$ 20.00$ to $\$ 22.00$ per ton.

"Alfalfa is the most enriching crop we have and ensures large yields to the other crops that follow. Alfalfa adds humus to the soil, resists drought better than any other crop."

OTHERS NOW BECOMING INTERESTED IN ALFALFA.

Dear Sir:

Jefferson, Ohio.

Some years ago I got some Alfalfa seed from you which was very satisfactory and I am planning to sow a couple of acres and would like to know your prices on good seed, at least three pecks. Please let me know as soon as possible; there are probably others who will send to you through me.

M. SEIBOLD JEFFERSON.

SEED FULLY EQUAL TO SAMPLE, WELL PLEASED.

Dear Sir:

Holland, Mich.

I have now received the seed in good condition and am very well pleased with it, as we find the seed as good as the sample you sent me. Yours very respectfully,

BERT VAN KAMPEN.

SIX TONS ALFALFA PER A., WORTH $\$ 75.00$ OR MORE.

Gentlemen:

St. Charles, Iowa.

I want to say that the seed I bought of you three yars ago has done real well for me. It gave me a No. 1 stand and each year since I have cut four heavy crops of Alfalfa, last year making a fraction over five tons per acre. The first two crops this year were much better than the two former years and the third crop for this year now stands knee high. It looks now as though I could safely count on six tons per acre. I have raised Alfalfa for eleven years in this county and have sown four different times and each time a success. Good land, proper seed bed, and best seed and sown with a drill is sure to win.

Have received the samples of Alfalfa seed and you will find enclosed my check for $\$ 40.10$, for World Brand Alfalfa. I examined the samples carefully and decided that the World Brand was the best to buy. Your very truly,

E. J. TRUMBAUER. 


\section{Alfalfa Facts Worth Remembering}

Grow Gold on your farm.

Alfalfa is King of forage crops.

Don't sow poor or weedy seed.

Alfalfa is ideal feed for dairying.

Alfalfa makes an ideal soiling plant.

Select fertile land that is well drained.

Alfalfa is one of the best of soil builders.

Alfalfa is a surer crop in Iowa than Clover.

Don't give up if your first attempt is a failure.

Use precaution when starting to pasture Alfalfa.

Early Potatoes is a splendid crop to precede Alfalfa.

Alfalfa hay is the forage crop to grow for largest returns.

When using a nurse crop sow the grain very sparingly.

Don't fail to keep the weeds clipped on spring seeding.

Soil free from weeds is much better adapted to Alfalfa.

Alfalfa should be cut when about one-tenth in blossom.

An Alfalfa field should never be pastured the first season.

Don't try to save money by the purchase of cheap seed.

Every acre that grows Alfalfa increases the value $\$ 100.00$.

Alfalfa will not grow where the water is near the surface.

Use 15 pounds of our World Brand Alfalfa seed to an acre.

A ton of Alfalfa hay is equal to a ton of bran is feed value.

Inoculation is essential for the successful growing of the Alfalfa.

Soil often requires liming for the best success of the Alfalfa.

Don't be satisfied until you are growing Alfalfa on your farm.

Don't lose the leaves; they constitute the best part of the hay. You can grow Alfalfa on your farm by following instructions. Don't sow on any but a finely prepared, well settled seed bed. Increased production can be expected by inoculating the seed. Alfalfa hay should be put under cover, as it does not shed rain. Use a spring tooth harrow to eradicate blue grass in an old Alfalfa field.

Alfalfa should never be pastured off close, as it will cause weeds to start.

Iour success with Alfalfa depends quite largely on the preparation of the seed bed.

Alfalfa is one of the most highly nutritious and palatable of feeds for all classes of stock.

Alfalfa will grow successfully on a larger per cent of the farms in the United States than any other plant. 


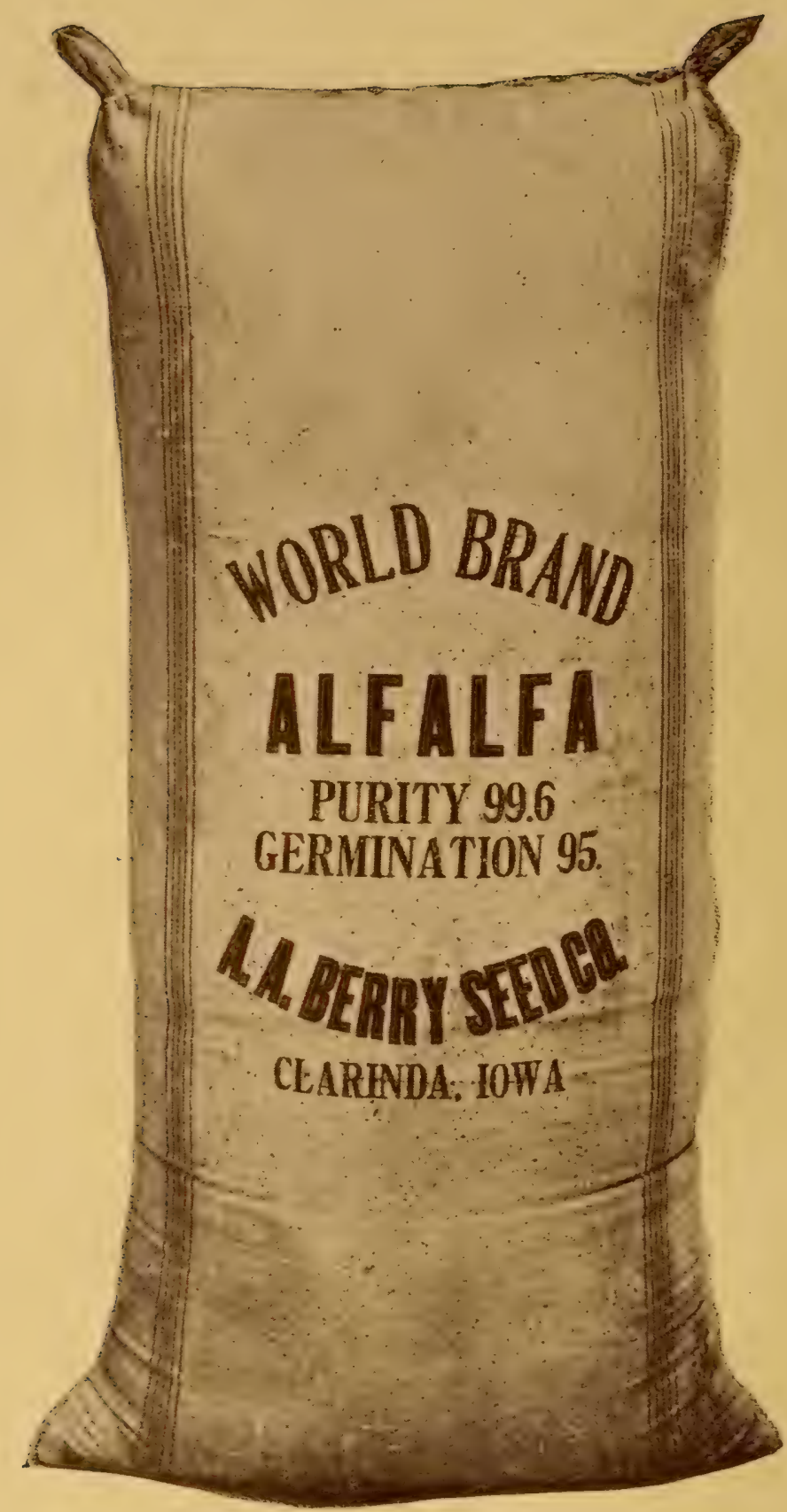




\section{Planters' Seed Table}

\section{LEGAL WEIGHTS TO BUSHEL IN IOWA.}

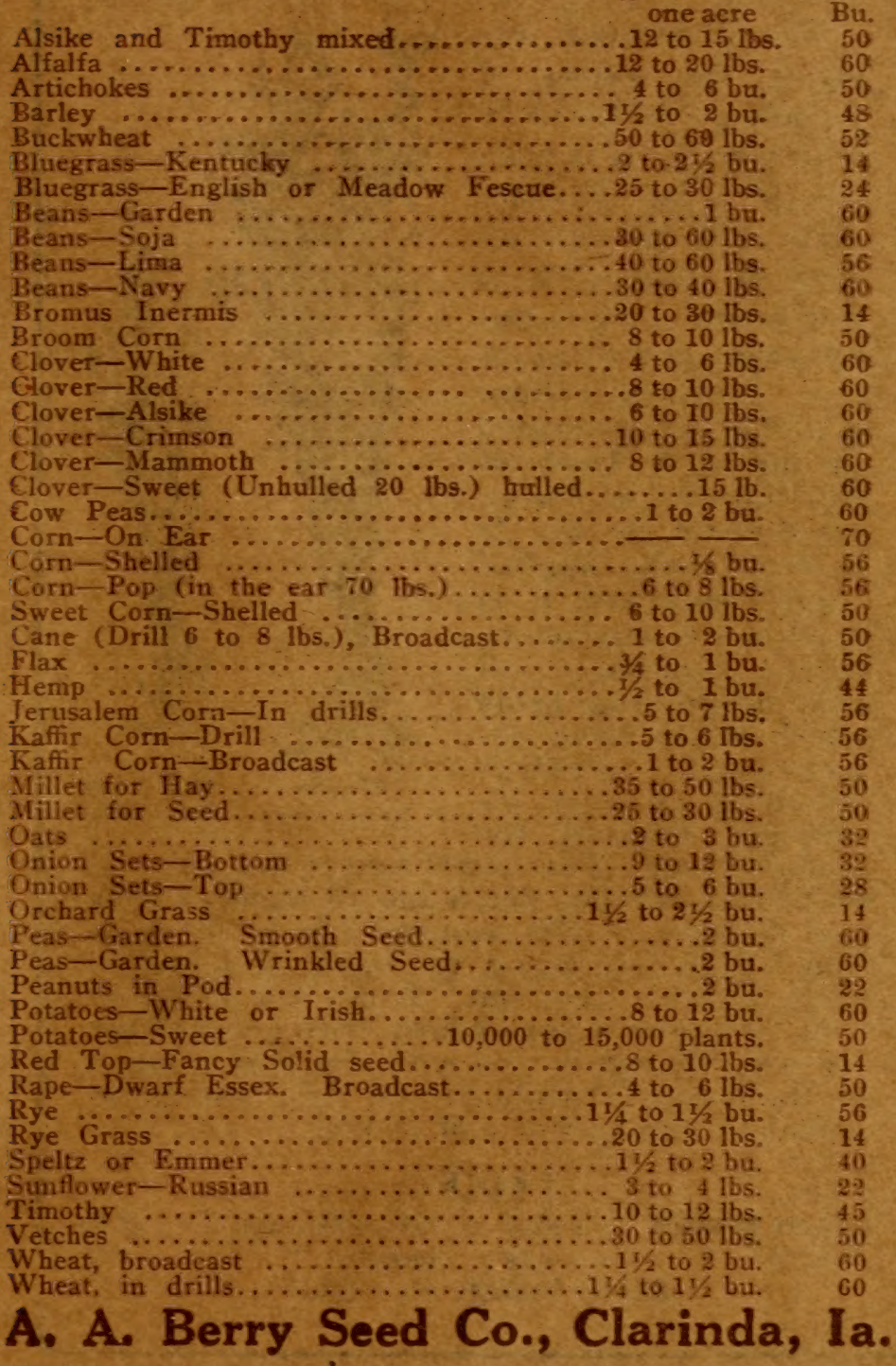




\section{Use Nodule-ǵerm Culture}

And Watch the Increased Results

The illustration explains the results of Nodule-germ better than words. It is marvelous what Nodulegerm will do and we want to urge you to use it and test it out by your own observation. Nitrogen culture is highly recommended by the U. S. Dept. of Agriculture, in Farmers Bulletin No. 315. It is very easily applied to the seed and it is much more satisfactory than obtaining soil from neighboring fields which might have objectionable weeds. There is an ever increasing demand for

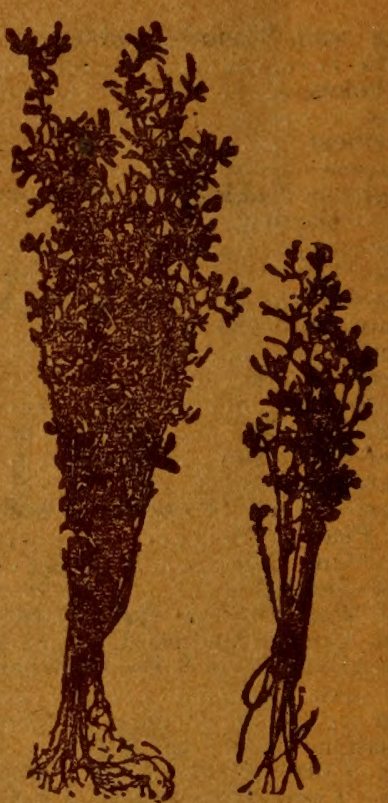

Alfalfa Alfalfa not Inoculated Inoculated

Nodule-germ. The best farmers are using it on Clover, Alfalfa, Vetch and all legumes. You can increase results wonderfully by inoculation. Full description for using is found in every package sent out. Don't fail to let us hear from you if you require Nitrogen Culture for we will supply you with the best product on the market at right prices. See catalog for complete description and prices.

\section{PRICES:}

$1 / 2$-Acre Package - . $\$ 0.60$ 1-Acre Package ... $\$ 1.00$ 5 -Acre $" \ldots .4 .00$ 10-Acre $\quad \ldots \quad \ldots 7.50$ 20-Acre Package - . \$ \$14.00 


\section{SAVE MONEY}

\section{When Buying Your Grass Seed}

You can do this by buying direct from the producing section. We are producers and also buy direct from the farmers, so that we can offer Grass Seed at most reasonable prices.

We sell many carloads each season of Clover, Timothy, Alfalfa and Grass Seeds of all kinds, saving our customers from $\$ 1.00$ to $\$ 2.00$ per bushel on both Clover and Alfalfa.

We can save you money by dealing direct with us. You eliminate the jobber's and retail merchant's profit by sending to us for seed.

We handle our seed on a very close margin. What we save in buying is gain for our customers. Get our samples and prices and see for yourself that it is to your interest to favor us with your patronage.

All seeds tested and guaranteed to be satisfactory in every way. Any time you buy Grass Seed from us and are not satisfied in every way, you can send the seed back and we will pay freight both ways and refund you the amount paid for it.

Don't forget us as we are headquarters for Grass and Field Seeds of all kinds.

\section{A. A. BERRY SEED CO. CLARINDA, IOWA}




\section{LIBRARY OF CONGRESS}
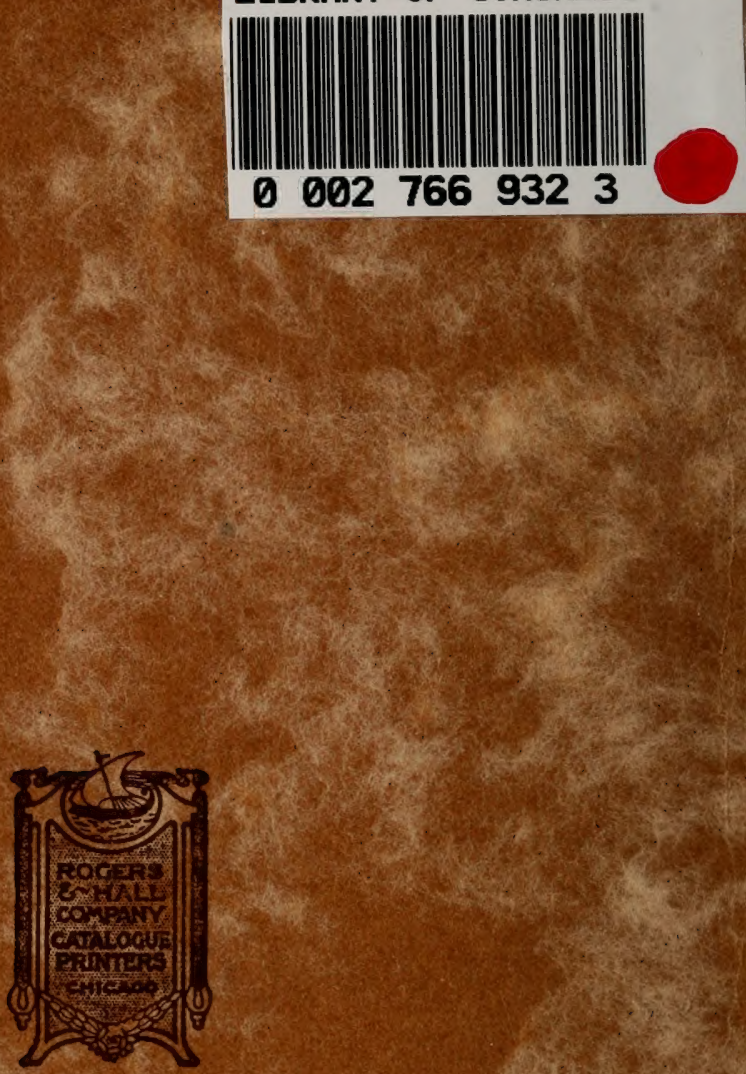